\title{
DEFENDING THE STATE AS A FORM OF LOVE FOR THE FATHERLAND IN AN ISLAMIC PERSPECTIVE
}

\author{
Zam Zami \\ STAIS Dharma Indramayu \\ Email: guszamie_ca@yahoo.co.id
}

\begin{abstract}
Transnational ideology springs the faded attitude of state defends. On another side, state defend is always connected with the military. The concept of jihad (struggle) in the Qur'an can be understood as an obligation to defend the state at all levels. The obligation could be in the form of guarding unity and integrity, culturalizing of deliberation, struggling justice, and maintaining freedom. The obligation of state defends in the form of physical form could not be conducted whether individually or collectively. This obligation is performed only if a ruler commands to battle against, and when an enemy has besieged a region. If defending Indonesia's state is one of the requirements for the existence and glory of Muslims in materializing Islamic values and universal of humanity, so struggling for state defend is a condition sine qua non.
\end{abstract}

Keywords: Defending the Country, Love the Fatherland, Islamic Perspective

\section{A. INTRODUCTION}

Nationalism is a modern concept that emerged in the 17th century along with the birth of the concept of the nation state. In Europe, nationalism emerged as a manifestation of resistance to feudalism (absolute power held by religious leaders and aristocrats). Along with the emergence of the nation state, various thoughts about nationalism emerged as the philosophical basis for the formation of the nation state. Jamaluddin says that a nation is formed because of the elements and historical roots that shape it. Therefore, it takes the thought that the highest dedication of a human being to the nation and state is called nationalism (Jamaludin, 2015. p.16).

At least there are several concepts of unity or brotherhood in Islam known as ukhuwah (brotherhood), namely ukhuwah Islamiyah (Muslim brotherhood), ukhuwah wathaniyyah (national brotherhood) and ukhuwah basyariyah (human brotherhood). In this study, the author wants to emphasize the importance of ukhuwah wathaniyah and ukhuwah basyariyah. The author is of the view that ukhuwah wathaniyah (national brotherhood) must take precedence and priority because without a state, Muslims will not be able to carry out their religious activities. In this connection, nationalism or love for the country is built on the noble values that already exist in every human being.

As an understanding or teaching that emerged from the West (Europe), nationalism was interpreted in various ways by various Islamic groups in the country. The concept of homeland love, which is actually at the level of the physical spirit of every human being, must be translated into various thoughts related to the love relationship between the motherland and Islam. Siroj says that Islam and the state are inseparable things (Siroj, 2015. p. 6). The meaning of society about the concept of state and religion continues to be a massive problem among academics, scholars' and state leaders (Jamaludin, 2015. p.17)

Currently, the enthusiasm to defend the country as a form of love for the homeland seems to have faded in the midst of the emergence of a transnational ideology that is "dressed in Islam". Even though defending the country can be classified as a form of jihad, in a broad sense. Especially when it is done in order to defend the rights of Muslims in particular, and human values in general. Therefore, the 
efforts of every citizen to defend the Republic of Indonesia against threats both from outside and within the country are a necessity for the existence of the nation.

There is no explicit discussion about defending the country in the Qur'an textually, most of the editors of the verse use jihad fi sabilillah (jihad in the way of Allah). However, signs about the importance of building a country that is good (baldah tayyibah), just and prosperous under the protection of God the Most Forgiving are mentioned in QS. Saba [34]: 15 so emphatic and clear. This seems impossible if it is not accompanied by the love of a nation for its homeland, with "jihad" or the sincerity of the people and leaders to defend the country. This is as indicated in the story of the Al-Qur'an (QS. An-Naml [27]: 34), how the high-ranking officials of the kingdom of Saba 'were very worried if there was an "attack" from outside that devastated their country. So all efforts were made, including lobbying to give gifts to Prophet Solomon. It is because they really love their country. In other words, their nationalism is so great to defend their country.

Unfortunately, defending the country is usually associated with military or militarism. It is as if the obligation and responsibility to defend and defend the country lies only with the Indonesian National Army. Whereas based on Article 30 of the 1945 Constitution, state defense (ad-difa 'an al-balad) is the right and obligation of every citizen of the Republic of Indonesia. UU no. 3 of 2002 concerning National Defense of the Republic of Indonesia regulates the procedures for the implementation of state defense carried out by the Indonesian National Army (TNI) and all components of the nation.

Al-Quran as the holy book of Muslims does not explain directly (textually) the importance of defending the country (ad-difa 'an al-balad) as a form of love for the country (hubb al-wathan), but the values contained in it able to answer all kinds of questions about the importance of defending the country and loving the country (Wahid, 2015. p.20). Among these values is the spirit of unity and integrity (ukhuwah wathaniyah) and guidance to always respect and respect fellow human beings. The Koran has explained how human attitudes towards the state. However, the contemporary problem in the 21st century is the erosion of state defense and the love of the homeland of citizens. Admittedly or not, the attitude of rejection of the concept of a nation state is still often heard in the community. This research confirms the concept or idea of defending the country as a form of love for the country in the Koran which is strengthened by the study of the sources of Islamic law.

\section{B. METHOD}

This study uses a library research approach. This research is oriented towards collecting data contained in various available reading sources. Various library materials and information data used come from various books, scientific journals, mass media both printed and electronic, government data, articles and other reading sources. This type of research is also one that focuses on developing theory or finding solutions to problems that are idea in nature.

According to Zed there are at least four main characteristics of library research. First, the researcher is dealing directly with text (nash) or numerical data which is not based on direct knowledge in the field. Second, the library data is permanent or ready to use. Third, literature is a secondary source or data in the sense that the researcher obtains it from a second party. Fourth, the library data condition is not limited by time and space (Zed, 2014. p.4-5). This research also uses manuscript study. Namely, research on Qur'anic texts that discuss a particular problem.

The data collection technique used in this study is a research technique using the documentation method. This documentation method is one of the activities to find data on several things, which can be in the form of notes, books, articles, mass media, and several other reading sources whose truth can 
be accepted based on existing scientific studies. Based on the use of the references above, the researcher can use two models of study or analysis of the studies carried out. Deductive analysis is carried out based on existing and relevant general theories or concepts as well as inductive analysis which is carried out based on the synthesis of previous research. From this context, this research was developed to examine the values of defending the country and loving the country from an Islamic perspective.

\section{RESULTS AND DISCUSSION}

\section{State Concept}

The state is a community of individuals, permanently inhabiting certain areas, legally demanding selfindependence from the outside and having a government organization, by creating and implementing the law as a whole in the environment. Meanwhile, Phillimore as quoted by Abdul Mustaqim stated that the state is the people who permanently inhabit a certain area, bound by the laws of togetherness, customs and customs in one policy. From the two meanings above, it can be understood that in a state there are several components, namely territory, law, togetherness, wisdom and freedom to determine their own lives (Mustaqim, 2011. p.112).

Furthermore, in the imperial theory, the theory of state power and authority, it is stated that sovereignty and power are considered as forms of delegation of people's power to the rulers of the state. So, in essence, sovereignty belongs entirely to the people. Political rulers are simply institutions entrusted with holding (not controlling and dominating) and exercising sovereignty for the good of all the people. In the law of fiqh it says Tasharruf al-Imam manut bil maslahah. The ruler is accountable to the people and will automatically lose legitimacy if the exercise of his power violates the will of the people. The people have the same political rights and are the highest essence of state sovereignty.

\section{The Concept of Love for the Fatherland}

Initially, Islam did not recognize the term nationalism. There are only two known territorial-religious concepts, namely the area of peace (Darul Islam) and the area of war (Darul Harb). Therefore, the emergence of the concept of a nation state has generated several historical and conceptual tensions among Muslims. However, in Islam there are two terminologies that approach the concept of the nationstate, namely the words millah and ummah which mean society or ummah. However, the term refers to a socio-religious group rather than to a political community. On the other hand, the concept of the nation-state refers to the criteria of ethnicity, culture, language and territory and ignores religious elements. Meanwhile, at the institutional level, the concept of the nation-state collides with the concept of caliphate or panislamism (Azra, 1996. p.12).

Nationalism in the Islamic world can be learned from the history of Muslim countries in the world that are in direct contact with European societies and countries. Turkey is a Muslim country that openly accepts the concept of nationalism as in western countries. At that time, the Ottoman Empire controlled almost the entire Middle East region. These countries recognize and admire several European political concepts, including in the field of state administration and military (Azra, 1996. p.46).

Basically, the word love for the motherland in the Koran is not mentioned directly. However, the values contained in the Koran are found in the Koran. Various values of love for the country in the perspective of the Koran include the attitude of nationalism and willingness to sacrifice. Love for the motherland is a part of the noble values of the Koran. As exemplified by the prophets and apostles who have signaled the various phenomena and events that occur as valuable lessons in facing every changing period. 
The Koran is the holy book of the Islamic ummah that is believed and trusted. The Koran does not explain with certainty about the importance of loving the country (hubb al-Wathan) but the values contained in it are able to answer all kinds of questions about the importance of loving the motherland. Among these values are the spirit of unity and integrity (Ukhuwah Islamiyyah) and guidance to always respect and respect fellow human beings. This is one of the values of love for the motherland that is in the Koran. Of course, this value is not the only value that reflects the love of the motherland, but there are still many values contained in this word of Allah.

The following is a study of the Koran, Surat AlHujurat verse 13, which explains the concept of homeland love in an Islamic perspective.

Meaning: O people, Verily We created you from a man and a woman and made you nations and tribes so that you would know each other. Indeed, the most noble among you with Allah is the most devout among you. Indeed, Allah is All-knowing, All-Knowing (Kemenag, 2016. p.447).

Because the fall of this verse is Ibn Abi Hatim narrating from Abi Malakah who said, "After the liberation of the city of Mecca, Bilal went up to the Ka'bah and gave the call to prayer" (Al-Naisabury, 2009 p.264). Seeing this, some people then said, "How could this black slave who actually said the call to prayer on the Ka'bah!" some others said in a mocking tone, "Would Allah be angry if he did not say the call to prayer? Then Allah revealed this verse (As-Suyuthi, 2010. p.107).

Ibn Asakir narrated in the book alMubhamaat, this verse was revealed with regard to Abi Hindun, one time the Prophet ordered Bani Bayadhah to marry Abu Hindun to a woman from their tribe (Shaleh, 2003. p.457). However, they said, "O Messenger of Allah, how could we marry our daughter to a slave". Then this verse came down (asy-Suyuthi, 2011: 530). According to Al Imam Abul Fida Isma'il Q.S. Al Hujurat verse 13 emphasizes the unity of human origins by showing the same degree of humanity.

In Tafsir Al-Misbah says that the above verse can be interpreted as a form of human conscience towards the land of his birth or homeland (Shihab, 2014. p.445). That means they have had a love for their homeland since birth and that is a natural form. In line with this, the book Ar-Risalah by Hadratussyeckh Hasyim Asy'ari explains that defending a country that is experiencing colonialism is a must. From this opinion, the term Hubb Al-Wathan Minal Iman became known, which was popularized by $\mathrm{KH}$. Wahab Hasbullah. Furthermore, in interpreting the study of the Koran, the letter Al-Hujurat above, among Indonesian Muslims, nationalism is infused with the spirits of Islamic values. Muslim communities who practice their religion properly will have a sense of nationalism (Jamaludin, 2015. p.18).

\section{Defending the State as a Form of Love for the Fatherland in an Islamic Perspective}

The concept of defending the country (read: jihad) in an Islamic perspective is a dynamic concept, it can experience development in accordance with the context that surrounds it. Jihad to defend or defend the country according to the author's opinion is manifested in maintaining principles or values, including: ittihad (unity), al-shura (deliberation), al- 'adalah (justice), al-hurriyyah ma'a mas'uliyyah (freedom accompanied by responsibility), legal certainty, guarantee of haq al-ibad (HAM) and so on. This is what we must continually strive for in the context of jihad to defend the country. In the following, the authors will describe about it, namely:

1. Maintaining the Unity and National Unity 
One form of jihad to defend the country is to maintain the unity and integrity of the nation. In the Indonesian context, where the society is plural, both in terms of religion, ethnicity, language and nation, maintaining unity and integrity is a necessity. Moreover, Indonesia's territory consists of various islands that are "separated" and connected by oceans at the same time. This power cannot be attained without unity, and unity cannot be attained without brotherhood and togetherness and a willingness to respect one another.

In the Qur'an, the command to maintain unity and integrity is very clear, as stated in the QS. alAnbiya '[21]: 92: "Surely your people are one people ...". This is corroborated by the verse Al-Qur'an sura Ali Imran verse 103 which forbids us to divorce. Likewise, Al-Qur'an surah al-Anfal verse 46 also prohibits arguing or arguing with each other, because it will weaken our strength.

\section{Inculcating Religious Nationalism Values}

Nationalism is simply a notion that creates and maintains the sovereignty of a country (in English "nation") by realizing a common identity concept for a group of people. What the author means is religious nationalism which is based on religious values and spirit. This means that religion becomes a spirit and value to uphold a just and prosperous country. In other words, the relationship between religion and state can be symbiotic and mutually beneficial. However, do not let religious politicization occur for pragmatic interests of the state elite. Do not let the jihad to defend the state here be ridden by certain elites in the interest of perpetuating the same power. For this reason, criticism and "loyal opposition" to the government are needed, so that the government or the state does not politicize religion in order to secure power.

\section{Cultivating Syura (Deliberation)}

Deliberation can mean saying or proposing an opinion. Deliberation (syura) is basically only used for good things, in line with its basic meaning (Shihab, 1999. p.469). In other words, deliberation decisions cannot be applied to legitimize actions that will oppress other parties and are inconsistent with human values. Borrowing the language of the Al-Qur'an, don't let the shura aim at justifying what is haram and haram what is lawful, which is clearly written in the Qur'an or Sunnah.

In determining decisions related to people's lives, humans recognize at least three ways, namely: 1) decisions made by the authorities; 2) decisions made by minority views; 3 ) decisions are made based on the view of the majority, and this is usually a general feature of democracy, although it should be noted that democracy is not synonymous with shura (Shihab, 1999. p.469).

The principle of deliberation in the Al-Qur'an is clearly not in accordance with the first decision model, because it will make shura "impotent" and paralyzed. Likewise in the second form, because it will leave the question of what the privilege of minority opinion is to defeat the majority. Indeed, there are some experts who reject majority authority. This opinion is based on the word of Allah: "Bad is not the same as good, even though the amount of bad is pleasing to you" (Surah Al-Maidah [5]: 100). However, this view is difficult for us to accept, because the verse does not speak in the context of deliberation, but in the context of Allah's guidance given to the Prophets and rejected by some members of the community at that time.

\section{Fighting for Justice (al-'Adalah)}

In managing the government, justice (al-'adalah) is a necessity, because the government is formed, among other things, in order to create an atmosphere of a just and prosperous society. It is not an 
exaggeration if then Shaykh al-Mawardî in al-Ahkam as-Sultaniyyah includes the first requirement for an imam or a state leader to have the character of al-'adalah or fairness. Even some scholars, there are those who argue that a just government under an infidel leader is better than a Muslim leader but wrongdoer. Because justice in leading is an absolute condition for the creation of "real" social stability, not social stability "as if" due to pressure. In the Al-Qur'an, the concept of justice is expressed in the words al-'adl, al-qist, al-mizan. Justice according to the Al-Qur'an, will lead to piety (QS. Al-Ma'idah [5]: 8) and piety will lead to prosperity (Surah Al-A'raf [7]: 96).

\section{Maintaining the Principle of Freedom (al-Hurriyyah)}

Freedom or al-hurriyyah in the view of the Al-Qur'an is highly respected, including the freedom to make religious choices though (QS. Al-Baqarah [2]: 256). Even explicitly Allah gives freedom (Surah Al-Kahf [18]: 19) whether someone wants to believe or disbelieve (Surat al-Kahf (18) verse 19). Because, freedom is the right of every human being given by Allah Almighty, there is no revocation of the right to freedom except under and after going through a legal process.

However, the freedom demanded by Islam is responsible freedom. Freedom here also does not mean freedom without limits, at will, but freedom that is limited by the freedom of others. An example is that a person may not under the pretext of freedom, then turn on the radio as loud as possible, but at the same time interfere with the freedom of others to rest comfortably, because of the sound of the radio.

In connection with the love of the motherland, the ulama 'Indonesia issued an opinion about the love of the motherland for all citizens. In the decision of the Indonesian Ulema Council (MUI), defending the homeland is mandatory. The most popular expression among Indonesians is the opinion of ulama 'which expresses the sentence: Love for the motherland is part of faith. If seen from the meaning of the word, the sentence "Hubb" means love or pleasure or a sense of belonging. "Al Wathan" can be interpreted as the homeland or land where blood was spilled or the land of birth. "Min" is the letter jer which can be interpreted as or part of. The word "Al Iman" means belief or monotheism. Faith also means the highest human feeling of belief in his god. Meanwhile, when viewed as a single sentence, then "Hubb Al Wathan Minal Iman" can mean that love for the country is part of faith (Jamaluddin, 2015: 16).

The ulama's ijtihad 'is inseparable from the NU jihad resolution fatwa issued by $\mathrm{KH}$. Hasyim Asy'ari in 1945. The meaning of the jihad resolution means the obligation of every Muslim to fight for the defense of the Indonesian state and nation in the face of Dutch and Japanese colonialism. The jihad resolution became one of the triggers for the enthusiasm of the Indonesian people in the November 101945 war in Surabaya, which was the biggest resistance of the Indonesian nation after the Proclamation of Independence of the Republic of Indonesia.

$\mathrm{KH}$. Hasyim Asy'ari called for resistance and struggle against the colonialists. The meaning contained in the verse "Hubb Al-Wathan" is a human servitude to their god. This does not mean making the homeland as a god or worship, but rather embodying feelings of love for Allah. Love for God is a human obligation. Human servitude to God can be marked by loving His creatures. One of them is by loving the homeland as an expression of gratitude for the grace of God who has given all its gifts. If we take a closer look, the meaning of the sentence "Hubb Al Wathan" is the love of the country as a form of gratitude for the abundance of God's gifts for his homeland. This is also in accordance with Maqasid Asy Syari'ah, including protecting religion, life, property, descent and homeland. 


\section{CONCLUSION}

Conceptually, the Qur'an does not define what a state is and what a state is, the terms that describe the components of a safe country and also the importance of having noble ideals requires a good state under the mercy of Allah SWT. The maintenance of a safe, just and prosperous country is part of the values of religious nationalism. Jihad in defending the country can be carried out by creating a harmonious atmosphere between the various components of the nation and this is an essential fabric of unity and integrity. In addition, the development of democracy based on deliberation and giving freedom of opinion is a framework for applicable national jihad that must not be abandoned. The estuary of all that is the creation of income distribution where the noble goal of the nation is to create social justice.

The obligation to defend the state is not individual and group in nature, its interests must also be national in nature. Defending the country physically can only be done when the wali al-amr (ruler/government) orders jihad and when the enemy has surrounded a country. When the enemy comes and enters a country and surrounds it, at that time jihad becomes fardlu 'ain for everyone. If defending the Indonesian State is one of the prerequisites for the upright and triumph of Muslims in carrying out Islamic values and universal humanity, then jihad to defend the state becomes a necessity (condition sine qua non).

\section{References}

Al-Naisabury, A. H. (2009). Asbab Al-Nuzul AlQuran. Dar al-Fikr Araby.

As-Suyuthi, J. A. b. A. B. (2010). Ad-Durrul Mantsur Fi At-Tafsiir Ma'tsur. Dar Al-Kutb Al-Imiyah.

Azra, A. (1996). Pergolakan Politik Islam: Dari Fundamentalisme, Modernisme Hingga PosModernisme. Paramadina.

Jamaludin, M. (2015). Nasionalisme Islam Nusantara: Nasionalisme Santri. Kompas Media Pustaka. Kemenag. (2016). Al-Qur'an dan Terjemahnya. Jakarta: Kementerian Agama Republik Indonesia.

Mustaqim, A. (2011). Bela Negara Dalam Perspektif Al-Qur'an (Sebuah Transformasi Makna Jihad). ANALISIS: Jurnal Studi Keislaman, XI (1).

Shaleh, Q. (2003). Asbabun Nuzul Latar Belakang Historis Turunnya Ayat-ayat. Dipenegoro Press.

Shihab, M. Q. (1999). Wawasan Al-Qur'an: Tafsir Maudhu'i atas Pelbagai Persoalan Umat. Bandung. Shihab, M. Q. (2014). Tafsir Al-Misbah: Pesan, Kesan dan Keserasian Al-Quran. Lentera Hati.

Siroj, S. A. (2015). Islam Nusantara. PT. Kompas Media Nusantara.

Wahid, S. (2015). Nasionalisme Islam Nusantara: Keindonesiaan dan Keislaman. Kompas Media.

Zed, M. (2014). Metode Penelitian Kepustakaan. Yayasan Obor Pustaka Indonesia. 